

\title{
Delayed Overshooting: It's an 80s Puzzle.*
}

\author{
Seong-Hoon $\mathrm{Kim}^{\dagger} \quad$ Seongman Moon ${ }^{\ddagger} \quad$ Carlos Velasco $^{\S}$
}

May 2014

\begin{abstract}
We re-investigate the delayed overshooting puzzle. We find that delayed overshooting is primarily a phenomenon of the 1980s when the Fed was under the chairmanship of Paul Volcker. Related findings are as follows: (1) Uncovered interest parity fails to hold during the Volcker era and tends to hold in the other periods considered. (2) US monetary policy shocks have substantial impacts on exchange rate variations but misleadingly appear to have small impacts when monetary policy regimes are pooled. In brief, we confirm Dornbusch's overshooting hypothesis.
\end{abstract}

Key words: delayed overshooting, UIP, Dornbusch overshooting hypothesis, Volcker, monetary policy regime

JEL Classification: F31, E52, E65.

${ }^{*}$ We are very grateful to the Editor (Harald Uhlig) and four anonymous referees for the comments which have substantially improved our paper. We would like to gratefully acknowledge research support from the Spanish Plan Nacional de I+D+I (ECO2010-19357, SEJ2007-62908, and ECO2012-31748).

${ }^{\dagger}$ Centre for Dynamic Macroeconomic Analysis, University of St Andrews, Fife, United Kingdom, KY16 9AR. Email: economicsnote@gmail.com

${ }^{\ddagger}$ Corresponding author: Department of Economics, Universidad Carlos III de Madrid, Calle Madrid 126, 28903 Getafe Madrid, SPAIN. Email: smoon@eco.uc3m.es, Tel.: +34-91-624-8668.

${ }_{\S}^{\S}$ Department of Economics, Universidad Carlos III de Madrid, Calle Madrid 126, 28903 Getafe Madrid, SPAIN. Email: Carlos.Velasco@uc3m.es, Tel.: +34-91-624-9646. 


\section{Introduction}

The delayed overshooting puzzle refers to an empirical tendency by which a domestic monetary contraction induces a protracted phase of appreciation of the domestic currency prior to a gradual depreciation. ${ }^{1}$ Re-investigating the puzzle, we examine the conditional response of exchange rates for 14 US trading partners over the 19742006 period. We identify US monetary policy shocks by using the method of sign restrictions developed by Uhlig (2005) and Scholl and Uhlig (2008). ${ }^{2}$

In an investigation of the puzzling behavior of exchange rates conditional on monetary policy shocks, a natural starting point is to consider recognizable shifts in the monetary policy regime. Our approach follows the simple procedure of comparing the behavior of exchange rates over four different periods: the entire sample period, the pre-Volcker era, the Volcker era, and the post-Volcker era. Arguably, the Volcker monetary policy regime is "the most widely discussed and visible macroeconomic event of the last 50 years of US history"(Goodfriend and King, 2005, p.981). ${ }^{3}$ Our division of the sample period based on historical episodes also coincides with the dates of structural breaks reported in the literature. For example, Bernanke and Mihov (1998) provide evidence of structural changes in 1980 and 1988 (or 1989), using Andrews (1993)' test for structural breaks with unknown dates. Concerning possible changes in the US Fed's reaction function proxied by the Taylor rule, Judd and Rudebusch (1998) also report statistical results that strongly reject the continuity hypotheses between the Burns-Miller and Volcker terms, and between the Volcker and Greenspan terms. ${ }^{4}$

\footnotetext{
${ }^{1}$ Eichenbaum and Evans (1995) and Grilli and Roubini (1996) document significant delayed overshooting (up to 3 years) based on a recursive identification scheme. This puzzling behavior is further confirmed by several subsequent studies that employ different identification schemes and/or different VAR specifications. See, e.g., Clarida and Gali (1994), Kim (2005), and Scholl and Uhlig (2008).

${ }^{2}$ We thank Almuth Scholl for kindly providing us with relevant matlab programs.

${ }^{3}$ One of the most notable features of the Volcker monetary policy regime is that the contemporary observers in the late 1970s and early 1980s considered the Volcker Fed's disinflation plan to be incredible and expected a policy "U-turn". In Section 6, we will examine the key features of the Volcker Fed in detail.

${ }^{4}$ Besides, a number of studies primarily focus on possible structural breaks after Volcker entered office and thus examine the "Volcker-Greenspan" years as one homogenous monetary regime. See, e.g., Taylor (1999), Clarida, Gali, and Gertler (2000), and Gali, Lopez-Salido, and Valles (2003). However, other works focus on the post-1984 period during which the US economy experienced both stabilized inflation and output changes. See, e.g., Stock and Watson (2002) and Gali and
} 
Our re-investigation finds, first, that the delayed overshooting in response to US monetary policy shocks appears to prevail in the entire sample period and, second, that one particular sample period, the Volcker era, is primarily responsible for the first result. Exchange rates overshoot immediately on impact of US monetary policy shocks during the post-Volcker era. ${ }^{5}$ The pre-Volcker era cannot be characterized by the traditional understanding of either delayed or immediate overshooting. ${ }^{6}$ In sum, the delayed overshooting during the Volcker era is severe enough to contaminate the entire sample period, thereby misleading previous empirical studies to prematurely conclude the failure of Dornbusch (1976)'s overshooting hypothesis.

One explanation for the results can be found in the close connection between the overshooting hypothesis and its key assumption, uncovered interest parity (UIP). Similarly to our results regarding the behavior of exchange rates, UIP, both conditional and unconditional, fails during the Volcker era but tends to hold during the pre-Volcker and post-Volcker eras. The conditional excess returns on foreign currency following US monetary shocks are positive in the Volcker era and close to zero in the other subsample periods. While this result concerns UIP conditional on monetary policy shocks, UIP unconditional on all possible shocks also fails during the Volcker era: using serial dependence tests, we find that the highly predictable foreign excess returns are only observed in the Volcker era. This result regarding the failure and prevalence of UIP is associated with the result regarding delayed overshooting and immediate overshooting. Our study confirms a close link between the overshooting hypothesis and the UIP assumption.

How important is the monetary policy regime in explaining observed exchange

Gambetti (2009). These studies adopt such a focus primarily because they are motivated by the Great Moderation and its key features, such as the primary policy instrument, policy mode (accommodative or preemptive), and the economy's responses to shocks, etc.

${ }^{5}$ Most existing empirical studies reporting a tendency of immediate overshooting employ identification schemes that relax the dubious assumptions required by the recursive identification method. See, e.g., Cushman and Zha (1997), Kim and Roubini (2000), and Bjornland (2009) for conditional responses to non-US monetary shocks and Faust and Rogers (2003) for those to US monetary shocks. In recent studies, Binder, Chen, and Zhang (2010) and Forni and Gambetti (2010) claim that the puzzle is eliminated once certain issues regarding the identification of monetary shocks, such as the reactions of other central banks to US monetary shocks or the sizes of the information sets held by central banks and private sectors, are properly accounted for. In contrast, we focus on recognizing shifts in the US monetary policy regime.

${ }^{6}$ Unlike other sample periods, the pre-Volcker era shows substantially different exchange rate behaviors across countries as reported in Section 3.1. 
rate movements? To address this question, we decompose the forecast error variance of the exchange rate movements within a Bayesian VAR framework. In contrast to previous studies, the maximal share of exchange rate fluctuations attributable to US monetary shocks is quite large for all subsample periods. More importantly, the share follows the same pattern as the impulse response of exchange rates: on average, US monetary policy shocks account for approximately $18 \%$ of the aggregate exchange rate (named AGGX) fluctuations over the 20- to 36-month horizon at the median estimate in the Volcker era, and for $36 \%$ and $43 \%$ of such fluctuations over the 1- to 4-month horizon in the pre-Volcker and post-Volcker eras, respectively. However, if we pool the subsample periods without considering the history of US monetary policy regimes, the monetary policy shocks seemingly account for little of the exchange rate fluctuations (at most $6.0 \%$ over a 5 -year horizon). This result occurs primarily because, owing to the large dispersion in the timing of maximal accountability across the subsample periods, the impacts of US monetary shocks on exchange rate fluctuations cancel one another out in the entire sample period. By implication, the failure to distinguish "the most widely discussed and visible" US monetary policy regime leads to the premature conclusion that Dornbusch's overshooting hypothesis fails to hold and that monetary shocks have little impacts on exchange rates.

The monetary policy regime matters. And it matters to a great extent. Provided that the processes that generate all other shocks have not experienced a structural break from one monetary regime to another, the unconditional movements of exchange rates in response to all possible shocks should also exhibit distinguishable movements between different monetary regimes. We test this prediction by using the variance ratio test for the serial dependence of exchange returns over long horizons. We find distinctly contrasting patterns of serial dependence in exchange rate movements between the Volcker era and the other subsample periods: only during the Volcker era do changes in exchange rates exhibit a hump-shaped pattern of serial dependence over long horizons. This result regarding the unconditional movements is fully consistent with an implication of delayed overshooting. Further, the serial correlations are consistently positive over a 5-year horizon, which suggests 
that exchange returns may contain a (near) non-stationary predictable component during the Volcker era. In brief, exchange rate behavior critically depends on the monetary policy regime itself.

The rest of this paper is organized as follows: Section 2 describes the data and identification methods. Section 3 documents the conditional behavior of exchange rates following US monetary policy shocks and establishes that delayed overshooting is primarily a phenomenon of the Volcker era. Section 4 reports the variability of exchange rates attributable to US monetary policy shocks and the unconditional behavior of exchange rates. Section 5 studies conditional and unconditional UIP. Section 6 proposes an explanation for the extraordinary behavior of exchange rates during the Volcker era. Section 7 concludes. Considering all of the relationships between conditional exchange rate movements and conditional UIP (Sections 3.1 \& 5.1), between conditional and unconditional exchange rate movements (Sections $3.1 \& 4.2$ ), and between conditional and unconditional UIP (Sections $5.1 \& 5.2$ ), we conclude that exchange rate movements and UIP are as cohesively related in data as they are in theory.

\section{Empirical Methods}

\subsection{Data}

Our data set covers 14 US trading partners: Austria (AT), Belgium (BE), Canada (CA), Denmark (DK), France (FR), Germany (GE), Italy (IT), Japan (JP), the Netherlands (NL), Norway (NO), Spain (ES), Sweden (SE), Switzerland (CH), and the United Kingdom (UK). It contains monthly data from 1974:01 to 2006:12. For the member countries of the European Monetary Union (EMU), the sample period ends in 1998. However, the sample period for GE is extended to 2006 by replacing the US-GE exchange rate with the US-Euro rate after 1998 based on the fixed GE-Euro rate. See the Appendix for the source of the data set.

Our discussion focuses on the aggregates of the 14 US trading partners. We construct aggregates by using two aggregation methods, named "AGG98" and "AGG". 
AGG98 uses all 14 trading partners prior to 1999 in consideration of the lifetime of EMU member currencies, where each country is weighed by its GDP relative to the total GDP for all 14 countries at purchasing power parity values. AGG extends the series until 2006 and considers the non-EMU countries plus GE, while treating GE as a representative of the EMU countries over the entire sample period (1974-2006). For example, the aggregate exchange rate corresponding to AGG98 is calculated by a GDP-weighted average of the 14 bilateral exchange rates. The aggregate exchange rate corresponding to AGG is constructed with the weight for GE calculated by the total EMU GDP relative to the total GDP for all 14 countries. The Appendix provides detailed information on the aggregation procedures.

Each series is divided into the three subsamples: the pre-Volcker, Volcker, and post-Volcker eras. The Volcker era spans from 1979:08 to 1987:12 for both the aggregates and the individual countries. The pre-Volcker era spans from 1974:01 to 1979:07. The post-Volcker era spans from 1988:01 to 1998:12 for AGG98 and from 1988:01 to 2006:12 for AGG.

\subsection{Identification of US Monetary Policy Shocks}

The main feature of our methodology is that we bring US monetary policy regimes to the fore of our empirical re-investigation of exchange rate behavior in response to US monetary policy shocks. To facilitate a comparison between our results and implications and those of previous studies, we control for all other methodological aspects and use similar empirical methods.

With respect to model specification, we follow Eichenbaum and Evans (1995). Our VAR specification includes seven variables: US and foreign industrial production $y$ and $y^{*}$, US and foreign 3-months interest rates $i$ and $i^{*}$, the ratio of US nonborrowed to total reserves $n b r x$, US consumer price index $p$, and the real exchange rate $s+p^{*}-p$, where $s$ is the nominal exchange rate defined as the price of the foreign currency in US dollar and $p^{*}$ is the foreign consumer price index. Throughout the paper, we consider the US to be the home country. When examining the behavior of nominal exchange rates, the VAR specification simply replaces the real exchange rate with the nominal exchange rate. All variables are in logs, 
except for the interest rates.

With respect to identification, we use Scholl and Uhlig (2008)'s method of applying sign restrictions on selected impulse response functions following a US contractionary monetary shock: "Identification I" in Scholl and Uhlig (2008, Table 1, p.4) requires that $p_{k_{1}} \leq 0$, nbr $x_{k_{1}} \leq 0$, and $i_{k_{1}} \geq 0$, for $k_{1}=0,1, \ldots, 11$ where $k_{1}$ denotes months from impact. ${ }^{7}$ That is, prices and nonborrowed reserve ratio are required not to rise and interest rates are required not to fall for one year in response to a US contractionary monetary shock. The advantage of the sign restrictions method, as argued by Faust and Rogers (2003), Uhlig (2005), and Scholl and Uhlig (2008), is that it precludes implausible responses of prices and interest rates to a monetary shock. For example, under the recursive identification methods that are used by Eichenbaum and Evans (1995), prices often rise in response to a monetary contraction (the price puzzle) and interest rates often fall in response to a monetary contraction (the liquidity puzzle) ${ }^{8}$. While this sign restrictions method helps to avoid such puzzles that exist under the recursive identification methods, it leaves the exchange rate unrestricted and thus our question agnostically open.

With respect to estimation method, we employ the Bayesian VAR procedure from Scholl and Uhlig (2008). We develop a Bayesian VAR with 6 lags and without a constant term and time trends. Assuming the Normal-Wishart family for the prior, we obtain results by taking draws from the posterior for the VAR coefficients that satisfy the sign restrictions: see Scholl and Uhlig (2008, pp.4-6) for the details of the estimation procedure and of the identification of monetary shocks. This Bayesian methodology has received some criticism regarding the interpretation of the error bands provided. For instance, Fry and Pagan (2011) indicate that these bands only describe uncertainty across models. However, our Bayesian procedure with a "flat" or "rotation-invariant" prior over the set of all possible impulse vectors in the appropriate orthonormalized space produces genuine confidence bands for the identified set of parameters (see Uhlig (2005)).

\footnotetext{
${ }^{7}$ The selection of the horizon of the sign restrictions is arbitrary. However, Scholl and Uhlig (2008) argue that with their identification scheme "Identification I", one year is a desirable horizon because it conforms to a sensible duration of the liquidity effect and reduces spurious effects.

${ }^{8}$ See Reichenstein (1987), Leeper and Gordon (1992), and Sims (1992) for details.
} 


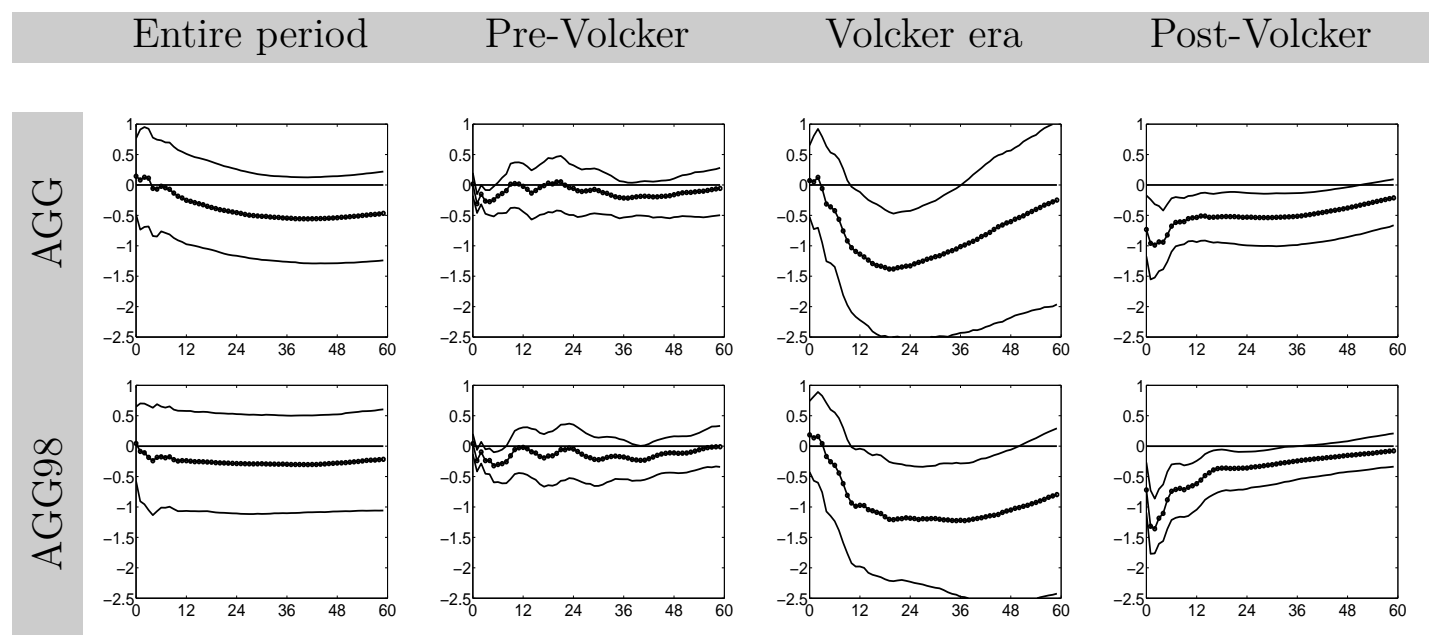

AGG: 7 non-EMU countries plus GE prior to 2007 and AGG98: 14 country pairs prior to 1999. The horizontal axis is in months. The median impulse response (line with circles) and the $16 \%$ and $84 \%$ quantiles of the distribution are shown.

Figure 1: Impulse responses of real exchange rates (benchmark model)

Throughout the paper, we refer to the 7 -variable VAR with the sign restrictions described above as the benchmark model.

\section{Empirical Results}

Dornbusch's overshooting hypothesis predicts that a currency will appreciate on impact and then gradually depreciate toward its long-run value in response to a contractionary monetary shock. We test this prediction and present the results for the three exclusive subsample periods and for the entire sample period.

\subsection{Overshooting}

Figure 1 plots the impulse response of the two aggregate real exchange rates to a US contractionary monetary policy shock. Following the convention in the literature, we present the 16,50 , and $84 \%$ quantiles of the posterior distribution for the points on the impulse response functions based on 5,000 draws. We focus on the behavior of exchange rates and provide the impulse response of other variables in the Online Supplement. First of all, we observe the following results from the median impulse responses of real exchange rates in Figure 1: 
- In the entire sample period, the exchange rates gradually fall and then return to their long run value (delayed overshooting).

- During the pre-Volcker era, the maximal response of exchange rates occurs over 1 to 5 months followed by irregular oscillation from 12 months onward (inconclusive).

- During the Volcker era, the maximal response of exchange rates is delayed over 20 to 36 months, similarly to the entire sample (delayed overshooting).

- During the post-Volcker era, the maximal appreciation of US real exchange rates occurs within 2 months followed by gradual depreciation (immediate overshooting).

In essence, these results indicate, first, that the delayed overshooting puzzle is substantially reduced in the pre-Volcker and post-Volcker eras and, second, that the puzzle's apparent persistence in the entire sample period is primarily driven by the behavior of exchange rates during the Volcker era. These key results are generally consistent with the behavior of real exchange rates for the individual country pairs. ${ }^{9}$

Nevertheless, the pre-Volcker era is difficult to characterize by the traditional sense of either delayed or immediate overshooting because the impulse response continually alternates between appreciation and depreciation phases. Further scrutiny at the individual country level reveals that the behavior of real exchange rates substantially differs across countries in a couple of dimensions: some individual exchange rates show immediate overshooting, while others do not; some show alternating responses; and some move in the opposite direction of that predicted by theory (see Figure B1 in the Appendix). These results suggest that the pre-Volcker era is substantially subject to country-specific factors.

Figure 2 complements the impulse response analysis: it presents the posterior distribution of the occurrence of the maximal response of real exchange rates (that

\footnotetext{
${ }^{9}$ One exception is that although the US-JP real exchange rate overshoots on impact in the post-Volcker era, it experiences another large gradual decrease before converging to its long run value. See Figure B1 in the Appendix for non-EMU countries and the Online Supplement for EUM members.
} 

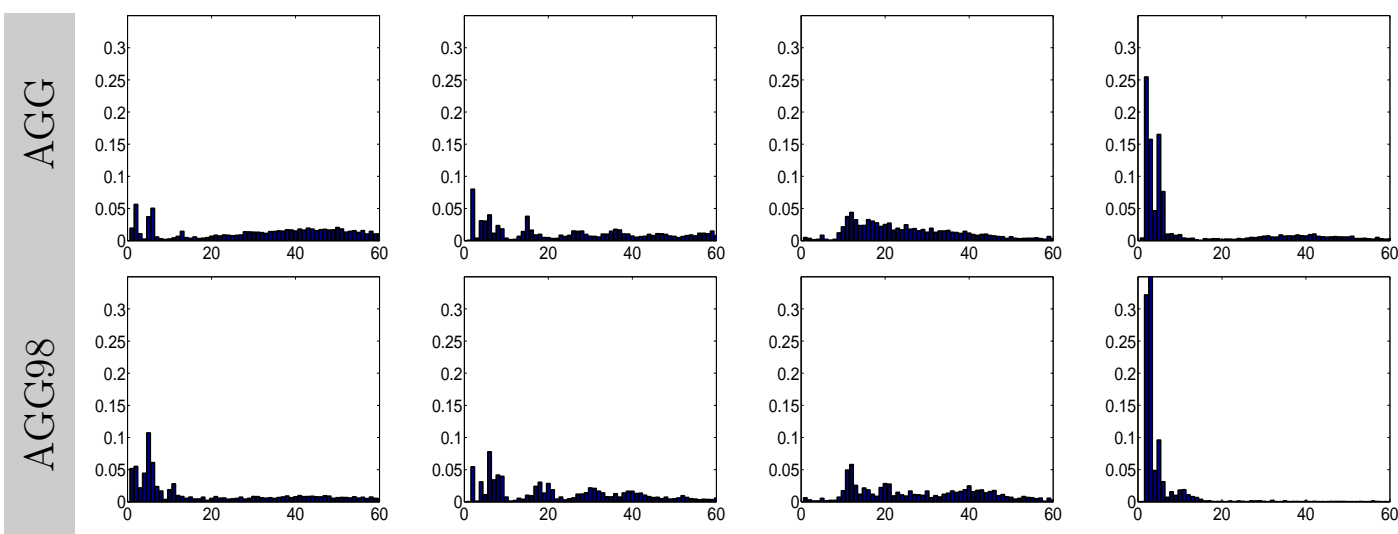

AGG: 7 non-EMU countries plus GE prior to 2007 and AGG98: 14 country pairs prior to 1999. The horizontal axis is in months and the vertical axis represents the frequency of month with the lowest value of each impulse response.

Figure 2: Posterior distribution of the timing of the maximal response of real exchange rates (benchmark model)

is, the distribution of the month with the lowest value of each impulse response drawn from the posterior). During the Volcker era, delayed overshooting behavior is evident for the two aggregate pairs, with the bulk of peak responses occurring between 10 and 50 months. Moreover, the probability of the peak appreciation of US real exchange rates occurring within 3 months remains merely 1\%, and even the probability of the peak appreciation occurring within 6 months remains only $2 \%$. During the post-Volcker era, in sharp contrast, the bulk of peak responses occur within 6 months. For example, the probability of the peak response of the US-AGG (US-AGG98) exchange rate occurring within 3 months is $47 \%$ (73\%), and the probability of the peak response occurring within 6 months is $70 \%(87 \%)$. This result is fully consistent across all 14 country pairs. However, during the pre-Volcker era, the probability of the peak response of the US-AGG (US-AGG98) exchange rate occurring within 3 months is only $12 \%$ (9\%), and the probability of the peak response occurring within 6 months is $21 \%$ (21\%), seemingly indicating the occurrence of delayed overshooting. However, examining those probabilities at the country level leads to the same conclusion as the impulse response analysis. In addition to visual comparison, we conduct a Chi square test for the homogeneity of 
two probability distributions for the month during which the maximal real exchange rate response occurs. At all conventional levels, we decisively reject the hypotheses that the distributions are the same between the Volcker and post-Volcker eras, between the Volcker and pre-Volcker eras, and between the post-Volcker and preVolcker eras. These results confirm our visual comparison.

Our key findings, on the one hand, are consistent with those of previous empirical studies such as Eichenbaum and Evans (1995) and Scholl and Uhlig (2008) but, on the other hand, are in sharp contrast to their conclusions regarding Dornbusch's overshooting hypothesis: similarly to these studies, the exchange rates exhibit delayed overshooting in the entire sample period, but in contrast to these studies, we find that the observed delayed overshooting behavior is attributed to a particular sample period. Our findings suggest that the very different responses of exchange rates between the Volcker and post-Volcker eras have misled previous empirical studies testing the Dornbusch hypothesis. Although the Volcker era represents only one-fourth of the entire sample in terms of the number of observations, its influence is substantial enough to contaminate the results for the entire sample period.

The real and nominal exchange rates behave very similarly at both the aggregate and individual levels. The robustness of the results to the use of either real or nominal exchange rates is consistent with previous studies. Henceforth, we will focus on the behavior of real exchange rates. In addition, the results for both USAGG and US-AGG98 real exchange rates are very similar. To conserve space, we will only report results for the US-AGG below. Unless indicated otherwise, we will relegate the results for the individual country pairs to the Online Supplement.

\subsection{Robustness}

We conduct robustness exercises based on several methods involving different identification schemes and VAR specifications. Specifically, we consider (i) a 7-variable model with recursive identification, (ii) a structural factor model with recursive identification, (iii) a 12-variable model with sign restrictions, and (iv) sensitivity analysis of the benchmark model in various directions. Overall, we find that the conclusions from the benchmark model remain unchanged. 


\section{Entire period Pre-Volcker era Volcker era Post-Volcker era}

(i) A 7-variable model with recursive identification
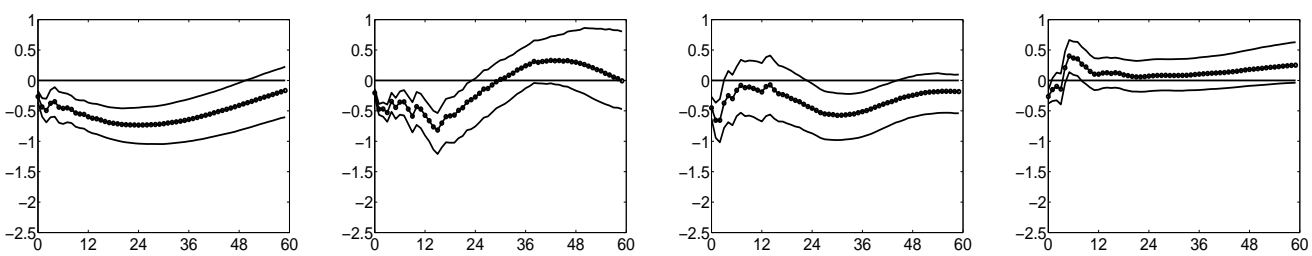

(ii) A structural factor model with recursive identification
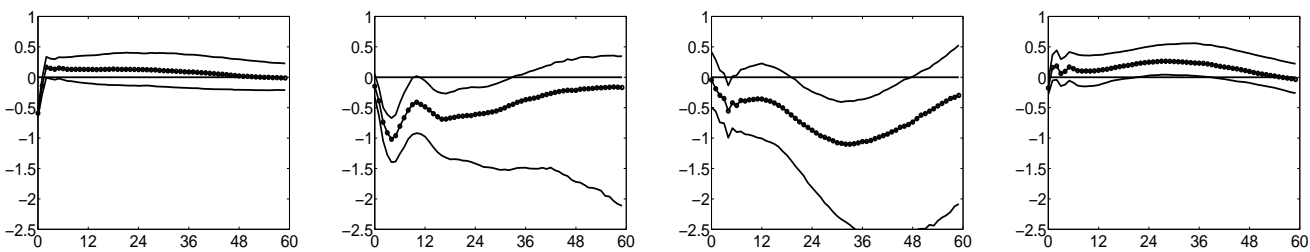

(iii) A 12-variable model with sign restrictions
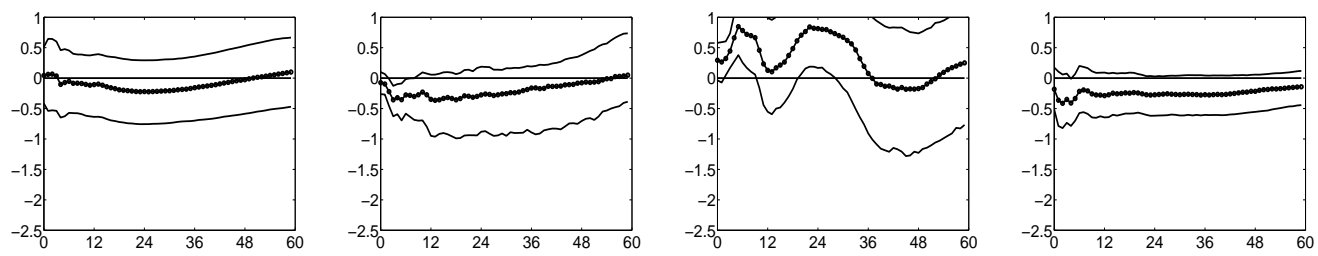

AGG: 7 non-EMU countries plus GE prior to 2007. The horizontal axis is in months. The median impulse response (line with circles) and the $16 \%$ and $84 \%$ quantiles of the distribution are shown.

Figure 3: Robustness: Impulse responses of the US-AGG real exchange rate

Following Eichenbaum and Evans (1995), we consider a Cholesky identification scheme for monetary shocks based on the 7-variable VAR model in Section 2. We impose the recursive ordering $\left[y, p, y^{*}, i^{*}, n b r x, f, s+p^{*}-p\right]$ where $f$ is a federal funds rate, and define a US contractionary monetary shock by a positive innovation to $f$. As shown in the first panel of Figure 3, the results regarding the peak timing of the response of real exchange rates are in line with the benchmark model. For example, the maximal response of real exchange rates occurs on impact during the post-Volcker era and is significantly delayed in the entire sample period; during the Volcker era, the maximal response of real exchange rates is less salient than in the benchmark model, although it is qualitatively consistent with it; during the preVolcker era, the maximal response is somewhat more delayed. However, as it is well 
known, these results are accompanied by liquidity and price puzzles and somewhat sensitive to the measure of monetary policy shocks $(n b r x$ or $f) .{ }^{10}$

Following Forni and Gambetti (2010), we consider a structural factor model with recursive identification and take into account the difference in information sets between central banks (or private agents) and econometricians. ${ }^{11}$ To provide the best comparison possible, we use their data set and replace their real exchange rate and foreign interest rate data with ours. ${ }^{12}$ With this modification, the data set consists of 119 US monthly series. We also follow their baseline specification with 16 static factors, 4 dynamic factors (US industrial production index, US CPI index, federal funds rate, real exchange rate), and a lag length of 2. For the preVolcker and Volcker eras, we assume 10 static factors because of the relatively small sample sizes. Nevertheless, the number of static factors is much greater than that of dynamic factors, which is consistent with a suggestion from Forni and Gambetti. As shown in the second panel of Figure 3, the results are consistent with those of our benchmark model except with respect to the entire sample period, during which immediate overshooting occurs. ${ }^{13}$ However, we also find that this result is somewhat sensitive, as the maximal response is significantly delayed when 5 dynamic factors are used by adding nbrx to the previous specification. ${ }^{14}$ In addition, price puzzles arise in most cases like the 7 -variable VAR model with recursive identification.

Following Faust and Rogers (2003), we consider a 12-variable VAR model that includes foreign CPI, US and foreign long-term bond rates, US M1, and the US commodity price index in addition to the 7 variables in our benchmark model. ${ }^{15}$ We impose the non-positive sign restriction on the response of the US commodity

\footnotetext{
${ }^{10}$ Refer to the Online Supplement for additional details.

${ }^{11}$ One could consider FAVAR models developed by Bernanke, Boivin, and Eliasz (2005). But Forni and Gambetti (2010) show that their model nests the FAVAR approach when static and dynamic factors are equal in number and argue that their approach performs better in resolving the delayed overshooting puzzle with US data.

${ }^{12}$ We obtained their data set and matlab files from the Journal of Monetary Economics web page. We thank Luca Gambetti for providing us the detailed information on their data set.

${ }^{13}$ Note that the magnitude of impulse responses appears quite different from Forni and Gambetti (2010). However, this difference is due to the normalization: Forni and Gambetti normalize impulse responses of all variables by using the initial response of the federal funds rate, whereas we do not.

${ }^{14}$ Refer to the Online Supplement for further details.

${ }^{15}$ We did not include foreign monetary aggregates for reasons of data availability.
} 
price index to a US monetary contraction, in addition to the sign restrictions in the benchmark model. Because of the small number of observations relative to the number of variables, we set the lag length to 4 for the pre-Volcker era and 5 for the Volcker era. As shown in the third panel of Figure 3, the results regarding the peak response of real exchange rates are in general consistent with those from the benchmark model. However, during the Volcker era, the impulse response alternates between depreciation and appreciation before reaching the maximal response. The small sample size relative to the number of variables in the VAR may contribute to this result.

Finally, we conduct sensitivity analyses in several directions by (i) using the federal funds rate for the US interest rate in the benchmark model, (ii) including a constant term in the benchmark VAR, (iii) varying the lag lengths from 3 to 9; and (iv) varying the horizon of sign restrictions from 6 to 15 months. Overall, we find that the conclusions from the benchmark model remain unchanged with these variations. ${ }^{16}$

\section{Monetary Policy Effectiveness}

We have shown that the behavior of exchange rates conditional on US monetary policy shocks substantially differs between the Volcker era and the other subsample periods. Further, the behavior of exchange rates during the Volcker era is 'extraordinary' and 'overwhelming' in the sense that delayed overshooting is primarily observed for that particular period but misleadingly appears to be present throughout the entire sample period. In this section, we provide additional evidence supporting our characterization of delayed overshooting as a phenomenon of the 1980s and demonstrate the importance of distinguishing among monetary policy regimes in an investigation of exchange rate behavior.

\footnotetext{
${ }^{16}$ See the Online Supplement for further information.
} 

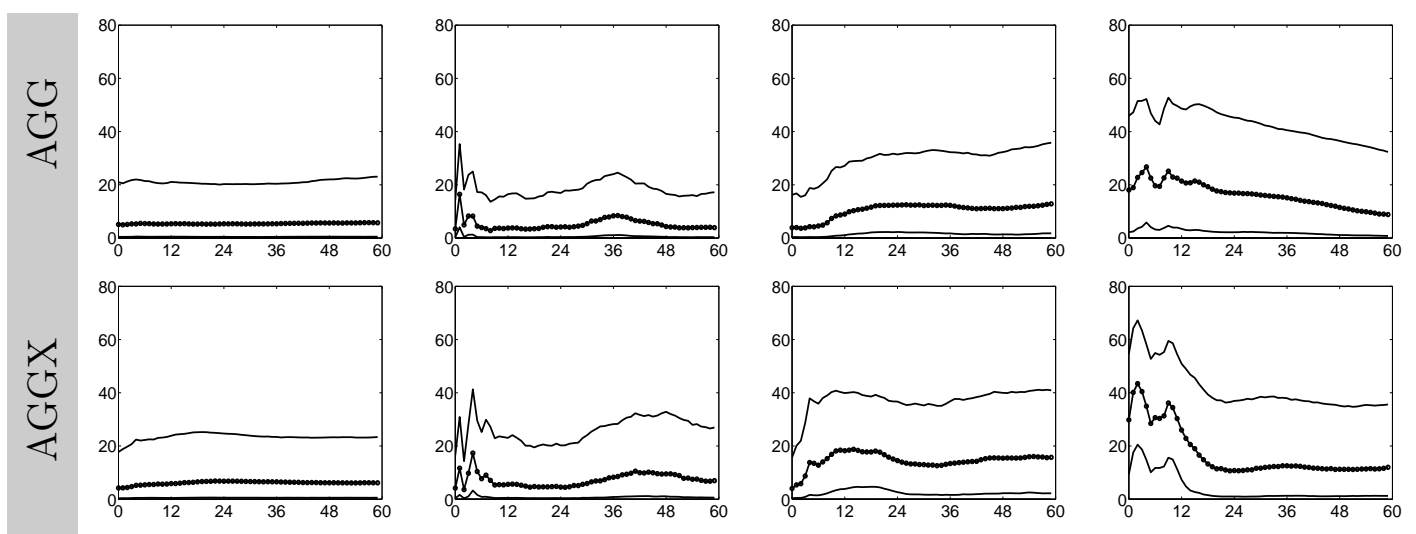

AGG: 7 non-EMU countries plus the GE prior to 2007 and AGGX: AGG excludes JP. The median (line with circles) and the $16 \%$ and $84 \%$ quantiles of the distribution are shown.

Figure 4: Forecast error variance decomposition for real exchange rate fluctuations (benchmark model)

\subsection{Exchange Rate Variability}

We conduct the forecast error variance decomposition for the US-AGG real exchange rate movements explained by a US contractionary monetary policy shock. Three results are immediate from the upper panel of Figure 4. The share of the forecast error variance of the aggregate exchange rate attributable to the US monetary shock

- follows the same pattern as its impulse response,

- varies significantly across sample periods, and

- appears to be far smaller than that at the individual country level in each of the three subsample periods.

Specifically, the maximal accountability of the US monetary policy shock occurs over 20 to 36 months at the median estimate in the Volcker era, around 1 to 4 months in the pre-Volcker and post-Volcker eras, and throughout the 5-year horizon in the entire sample period. Regarding magnitude, on average, the US monetary policy shock accounts for $12.4 \%$ of the exchange rate fluctuations over the 20 - to 36-month horizon in the Volcker era, $9.9 \%$ and $22.4 \%$ over the 1 - to 4 -month horizon in the pre-Volcker and post-Volcker eras, respectively, and 5.3\% over the 5-year horizon in the entire sample period. 
The first result is obvious in the sense that the time periods of the maximal accountability correspond to those of the maximal impulse response of exchange rates. However, this first result provides an important clue to understanding the second result, which effectively demonstrates the importance of distinguishing among monetary policy regimes, and helps to explain the third result. Based on the first result, we discuss two related effects that arise when data are pooled for different subsample periods and aggregated across countries. We will then argue that both pooling and aggregation effects mask the true accountability of US monetary shocks.

To understand the third result due to the effect of aggregation, we first compare the individual country pairs to the aggregate for the Volcker era. The maximal accountability occurs over the period from 10 to 48 months for the individual country pairs, which approximately corresponds to the period in which the maximal impulse response occurs [see Figures B1 and B2 in the Appendix]. Because of this extensive dispersion in the timing of their maximal accountability, individual exchange rate fluctuations attributable to the common US monetary shock cancel one another out in the aggregate. Thus, the share of the forecast error variance of the US-AGG rate is generally flattened over the 20- to 36-month horizon and smaller than that of the individual US bilateral rates. The aggregation effect also applies to the preVolcker era: the share of the exchange rate fluctuations is substantially reduced by aggregation.

We more explicitly confirm the aggregation effect for the post-Volcker era. At the individual level, the US-JP case appears to be somewhat exceptional with respect to the timing of the maximal accountability: it occurs at approximately 18 months, which is substantially delayed relative to that for the other country pairs. Such peculiar behavior, which may stem from country-specific factors beyond the scope of this paper, has a significant influence due to the substantial weight of JP in the aggregation. To observe this aggregation effect more explicitly, we consider another representative aggregate by removing JP from the rest of the world and name it AGGX. As shown in the lower panel of Figure 4, the magnitude of the accountability of a US monetary policy shock increases dramatically: It accounts for $43.2 \%$ of the US-AGGX exchange rate fluctuations, on average, over the 1 - to 
4-month horizon at the median estimate, which is twice as large as the case for the US-AGG rate. Apart from the US-JP rate, the aggregation effect is small in the post-Volcker era, as the periods of the maximal accountability that correspond to those of the maximal impulse response all remain within a small interval: 0 to 4 months for individual country pairs.

Bearing this aggregation effect in mind, we now examine the second result by investigating the effect of pooling the three subsample periods. As shown in Figure 4, the magnitude of the US-AGG real exchange rate fluctuations is very small in the entire sample period, supporting the results in Scholl and Uhlig (2008). However, the accountability of the US monetary shock is substantial at the 1- to 4-month horizon in the post-Volcker era but at the 20- to 36-month horizon in the Volcker era. Because of this extensive dispersion in the timing of the maximal accountability across the subsample periods, the exchange rate fluctuations cancel one another out in the pooled sample. Thus, the maximal accountability of the US monetary shock in the entire sample period is flattened throughout the 5-year horizon and is smaller than that in each of the subsample periods. This pattern also holds for the US-AGGX rate: the US monetary shock accounts for $5.4 \%$ of the exchange rate fluctuations, on average, over the 5-year horizon in the entire sample period.

This pooling effect is also present for each of the individual country pairs and explains why previous studies have reported a wide range of the share of exchange rate fluctuations attributable to US monetary policy shocks. For example, using monthly data from 1974:1 to 1990:5 during which the delayed overshooting appears to be most prominent, Eichenbaum and Evans (1995) report that US monetary policy shocks account for approximately 42, 26, and $23 \%$ of the exchange rate fluctuations for the US-GE, US-UK, and US-JP country pairs, respectively, at lags 31-36 (see also Clarida and Gali (1994)). However, using monthly data from 1975:07 to 2002:07, a coverage period that nearly overlaps with our entire sample period, Scholl and Uhlig (2008) report a share of approximately 10\% for the same countries at the same lags.

In brief, US monetary policy shocks account for a significant share of exchange rate fluctuations. In particular, they have a substantial and immediate impact 
on exchange rate fluctuations during the post-Volcker era. This result is in stark contrast with those of previous studies. We thus show that if one ignores the history of US monetary policy regimes and pools them all together, US monetary shocks misleadingly appear to have a small impact on exchange rate fluctuations.

\subsection{Serial Dependence of Exchange Returns}

The monetary policy regime matters. And very much. Therefore, one can infer that not only the conditional response of exchange rates to monetary shocks but also the unconditional average response of exchange rates to all possible shocks will show distinguishable movements between monetary policy regimes. In other words, if unconditional exchange rate movements inherit this conditional behavior, changes in exchange rates will exhibit strong, positive serial dependence during the Volcker era that reflects delayed overshooting behavior. We test this prediction with the variance ratio test for the serial dependence of exchange returns over long horizons. $^{17}$

We define the population variance ratio $V R(q)$ by

$$
\operatorname{VR}(q)=\frac{\operatorname{Var}\left(\sum_{l=0}^{q-1} \xi_{t+l}\right)}{q \operatorname{Var}\left(\xi_{t}\right)}=1+2 \sum_{l=1}^{q-1}\left(1-\frac{l}{q}\right) \gamma(l)
$$

where $\xi_{t+l}$ denotes the change in exchange rates between period $t+l-1$ and $t+l$; $q$ an accumulation horizon; and $\gamma(l)=\operatorname{Cov}\left(\xi_{t}, \xi_{t+l}\right) / \operatorname{Var}\left(\xi_{t}\right)$ the autocorrelation of exchange rate returns between $t$ and $t+l$. $V R(q)$ must be equal to 1 for each $q$ if the returns are not serially correlated. If the returns are positively (negatively) autocorrelated, $V R(q)$ should be greater (less) than 1.

Figure 5 shows the evolution of the t-values of the estimated variance ratios with respect to $q$ over a 5-year horizon. During the Volcker era, the t-values are all positive and substantially greater than the critical values at the $95 \%$ quantile of the empirical distribution throughout the 5-year horizon; further, the locus of $t$-values with $q$ is hump-shaped, having a peak between 18 and 36 months. ${ }^{18}$ These

\footnotetext{
${ }^{17}$ For information on tests for serial dependence over long horizons, refer to Fama and French (1988) and Moon and Velasco (2013) among others.

${ }^{18}$ We conduct our inference by using a wild bootstrap method to improve the finite sample
} 


\section{Entire period Pre-Volcker Volcker era Post-Volcker}
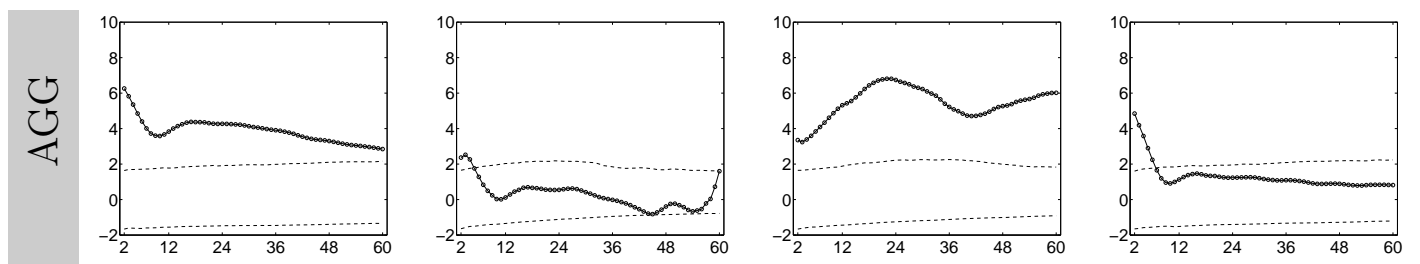

AGG: 7 non-EMU countries plus the GE prior to 2007. The horizontal axis is in months, corresponding to $q$. The vertical axis represents $t$-values. The line with circles represents the $t$-values of estimated variance ratios, and the two dashed lines are the $5 \%$ and $95 \%$ quantiles of the empirical distribution based on 5,000 draws.

Figure 5: Serial dependence of changes in real exchange rates

two features are consistent with the implications of delayed overshooting behavior. In contrast, in the other subsample periods, one can no longer observe a humpshaped pattern of serial dependence. The $t$-values of the estimated variance ratios are largest at 3 months in the pre-Volcker era and at 2 months in the post-Volcker era. Then, they rapidly decrease and remain inside the band with the critical values at the $5 \%$ and $95 \%$ quantiles for every $q$ beyond 4 months in the pre-Volcker era and beyond 6 months in the post-Volcker era. In the entire sample period, the $t$-values are all positive throughout the 5-year horizon and far above the critical values at the $95 \%$ quantile. Further, the locus of the $t$-values looks hump-shaped following a modest decrease in earlier months, indicating that the unconditional exchange rate behavior is also significantly influenced by the Volcker era.

In sum, the contrasting behavior of unconditional exchange rates between the Volcker era and the other subsample periods closely resembles that of conditional exchange rates in response to US monetary policy shocks in that (i) the behavior in the Volcker era is distinct from that in the other subsample periods and (ii) the influence of the Volcker era is so strong that pooling all subsample periods together can provide a misleading understanding of the true exchange rate behavior. Ultimately, the observation that the serial dependence pattern of unconditional exchange returns is also characterized by delayed overshooting suggests that conditional and unconditional exchange rate movements are closely linked during the properties of the variance ratio test based on Moon and Velasco (2013). 
Volcker era. Provided that no structural breaks occur in the processes that generate all other shocks, the behavior of unconditional real exchange returns highlights the importance of distinguishing among monetary policy regimes.

\section{Uncovered Interest Parity}

We have shown that Dornbusch's overshooting hypothesis mainly fails to hold in the 1980s but tends to hold in other periods. We now provide an explanation for this finding. A natural starting point is to examine the connection between the hypothesis' predictions and its key assumptions. Among other assumptions, we focus on UIP: It states that a currency with a higher interest rate will depreciate. If UIP holds, the US dollar should depreciate following immediate appreciation in response to a US contractionary monetary shock that leads to a higher US interest rate relative to the foreign interest rate. In this section, we investigate whether the subsample periods also significantly differ in terms of deviations from UIP. Overall, we find that the UIP assumption significantly fails during the Volcker era, when the overshooting hypothesis also fails; however, it tends to hold elsewhere when immediate overshooting also occurs. This new evidence supports the theory of exchange rate movements built on the UIP assumption and thus demonstrates that the delayed overshooting puzzle is a phenomenon of the 1980s.

\subsection{Conditional UIP}

We begin with conditional UIP in response to a monetary policy shock.

Let us consider the following trading strategy in response to a US contractionary monetary shock: An investor borrows in foreign currency for $k$ months, exchanges it for the US dollar, holds US treasury bills for $k$ months, and exchanges the interest rate returns on the US dollar back for the foreign currency $k$ months later. The return from this strategy between $j$ to $j+k$ is defined by

$$
\rho_{j+k}=\frac{1200}{k} *\left(s_{j}-s_{j+k}\right)+i_{j \mid k}-i_{j \mid k}^{*},
$$




\section{Entire period $\quad$ Pre-Volcker Volcker era Post-Volcker}
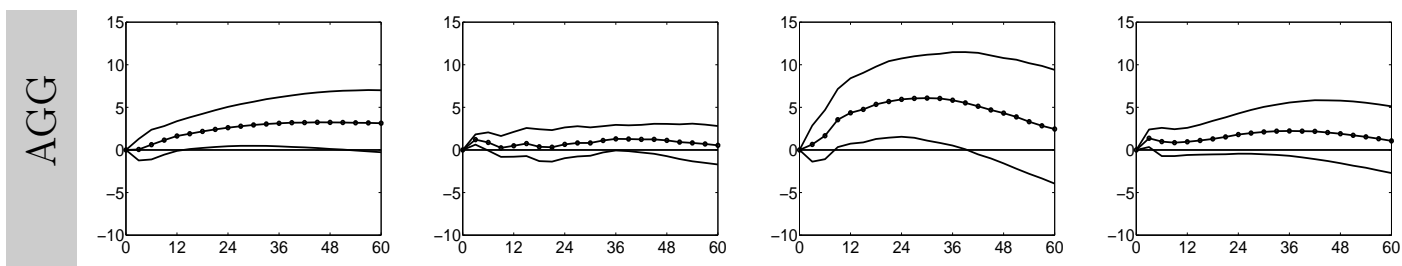

AGG: 7 non-EMU countries plus the GE prior to 2007. The horizontal axis is in months. The median impulse response (line with circles) and the $16 \%$ and $84 \%$ quantiles of the distribution are shown.

Figure 6: Conditional UIP: cumulated impulse responses of 3-month excess returns (benchmark model)

where $s_{j}$ is the impulse response of the nominal exchange rate in period $j$, and $i_{j \mid k}$ $\left(i_{j \mid k}^{*}\right)$ is the impulse response of $k$-month US (foreign) interest rates. We multiply $s_{j}-s_{j+k}$ by $\frac{1200}{k}$ to obtain annualized returns from this trading strategy. The cumulated returns from period 0 to period $T$ can be defined by

$$
\rho^{T}=\sum_{l=0}^{T / k-1} \rho_{l k+k} .
$$

Conditional UIP in our VAR analysis states $\rho_{l k+k}=0$ for all $l$ and thus $\rho^{T}=0$, under which the gain from the interest rate difference and the loss from the currency exchange should offset one another. Conversely, if the US dollar tends to persistently appreciate when the US interest rate is higher, the trading strategy will yield a positive gain with certainty from the interest rate difference as well as a positive average capital gain from the currency exchange. Overall, this strategy yields a positive return.

Figure 6 depicts the impulse responses of cumulated excess returns from the above trading strategy with the 3 -month holding period $(k=3)$, as our study uses 3-month interest rates. Note that to calculate excess returns, we replace real exchange rates with nominal exchange rates in our VAR specification. In the entire sample period, the cumulated excess returns are positive over the 5-year horizon in line with Scholl and Uhlig (2008). However, this behavior is driven by the particular sample period: the cumulated excess returns are positive over most of the horizon 
during the Volcker era but remain close to zero zero over most of the horizon in the other subsample periods, suggesting that conditional UIP is significantly violated during the Volcker era but tend to hold in the other periods. Furthermore, by implication, previous studies arguing for the failure of conditional UIP may have been misled by a failure to distinguish the effects of the Volcker era.

\subsection{Unconditional UIP}

We now turn to testing unconditional UIP. We investigate whether, similarly to conditional UIP, unconditional UIP tends to hold in the periods of immediate overshooting and does not hold in the periods of delayed overshooting. In so doing, our tests of unconditional UIP provide clues regarding the sources of the deviations from UIP, which have long been sought in the literature on the forward premium anomaly. ${ }^{19}$

We test unconditional UIP by examining the predictability of excess returns between time $t$ and $t+k$ defined by $s_{t}-s_{t+k}+i_{t \mid k}-i_{t \mid k}^{*} \cdot{ }^{20}$ UIP, under the assumptions of rational expectations and risk neutrality, implies no predictability of excess returns with the use of any variables in the current information set. To test this, we use the variance ratio test with some modification: Our previous variance ratio test in Section 4.2 tested the null hypothesis that real exchange rates follow a random walk. Here, the null hypothesis for the test of unconditional UIP is that $k$-period excess returns are not predictable. As data frequency (monthly) is finer than the forecasting interval ( $k$ month), we need to account for the moving average structure of forecasting errors for the variance ratio test. We adopt the sample splitting method developed by Moon and Velasco (2013).

Figure 7 presents the serial dependence of excess returns over a 5-year horizon. Note that because we are testing the predictability of 3-month excess returns, the unit of $q$ is now a quarter. During the Volcker era, the $t$-values of estimated variance ratios are all positive and much greater than the critical values at the $95 \%$ quantile

\footnotetext{
${ }^{19}$ See Lewis (1995) and Engel (1996) for the survey.

${ }^{20}$ Here we use subscript $t$ to denote a data point because unconditional excess returns are calculated directly from the data, whereas in (1) we use subscript $j$ to denote a point in the analysis horizon because conditional excess returns are calculated from our VAR model.
} 


\section{Entire period Pre-Volcker Volcker era Post-Volcker}
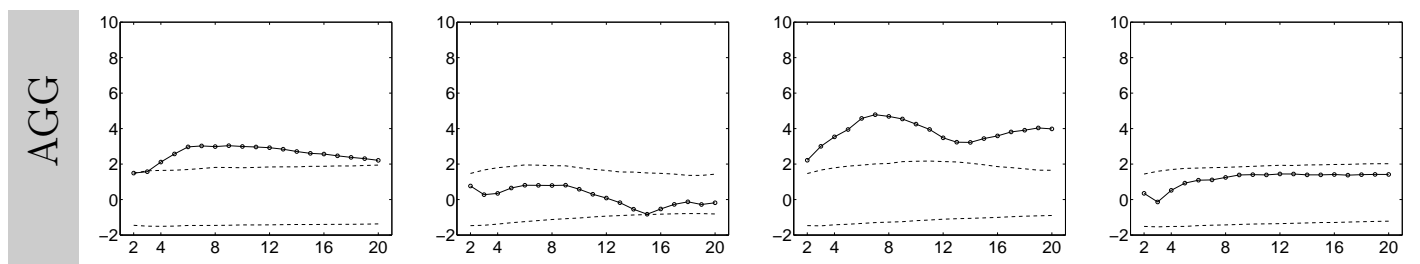

AGG: 7 non-EMU countries plus the GE prior to 2007. The horizontal axis is in quarters. The vertical axis represents $t$-values. The line with circles represents the $t$-values of estimated variance ratios, and the two dashed lines are the $5 \%$ and $95 \%$ quantiles of the empirical distribution based on 5,000 draws.

Figure 7: Unconditional UIP: Serial dependence of 3-month excess returns

of the empirical distribution throughout the horizon; further, the locus of $t$-values with $q$ is hump-shaped, having a peak between 5 and 10 quarters. This positive serial dependence pattern further indicates that predictable components in excess returns are not mean-reverting. In contrast, in the other subsample periods, the $t$ values remain inside the band with the critical values at the $5 \%$ and $95 \%$ quantiles, suggesting that excess returns are unpredictable. In the entire sample period, the $t$-values are all positive and above the critical values at the $95 \%$ quantile, indicating that deviations from UIP are significantly influenced by the Volcker era. These patterns of serial dependence across the subsample periods suggest that the conditional and unconditional movements of excess returns are closely linked. Again, provided that no structural breaks occur in the processes that generate all other shocks, the behavior of unconditional excess returns highlights the importance of distinguishing among monetary policy regimes.

Our result is compatible with the well-known empirical regularity called the forward premium anomaly, at least with respect to existing studies including the 1980s in their sample periods. To facilitate a comparison between our study and previous studies, we also consider the most popular test for UIP in the literature and run a regression of the excess return on the interest rate difference:

$$
s_{t+k}-s_{t}-i_{t \mid k}+i_{t \mid k}^{*}=\alpha+\beta\left(i_{t \mid k}-i_{t \mid k}^{*}\right)+u_{t+k}
$$

where $\alpha=0$ and $\beta=0$ under UIP. Table 1 reports the regression results for each 
Table 1: Excess return regression

\begin{tabular}{c|ccc|ccc|ccc|ccc|}
\hline & \multicolumn{3}{|c|}{ Entire period } & \multicolumn{3}{c|}{ Pre-Volcker era } & \multicolumn{3}{c|}{ Volcker era } & \multicolumn{3}{c}{ Post-Volcker era } \\
\hline \hline & $\hat{\beta}$ & $t$ & $R^{2}$ & $\hat{\beta}$ & $t$ & $R^{2}$ & $\hat{\beta}$ & $t$ & $R^{2}$ & $\hat{\beta}$ & $t$ & $R^{2}$ \\
\hline AGG & -2.41 & -3.20 & 0.03 & -0.81 & -0.57 & 0.00 & -5.66 & -2.44 & 0.13 & -2.27 & -2.34 & 0.02 \\
\hline AGGX & -2.07 & -2.28 & 0.01 & -1.22 & -0.91 & 0.00 & -5.84 & -2.40 & 0.11 & -1.82 & -1.59 & 0.01 \\
\hline
\end{tabular}

AGG: 7 non-EMU countries plus the GE prior to 2007 and AGGX: AGG excludes JP. $t$ is $t$-value of the estimate $\hat{\beta}$ in regression (2).

sample period. ${ }^{21}$ In the entire sample period, the conventional $t$-test rejects the UIP hypothesis. So does in the Volcker era. However, we do not reject the null in the pre-Volcker era. Although we reject the null in the post-Volcker era, the significance is substantially reduced when we exclude the US-JP exchange rate. Moreover, the explanatory power of the interest rate difference, measured by $R^{2}$, is nearly zero (if not zero) in the pre-Volcker and post-Volcker eras. This result is in sharp contrast with the magnitude of 0.13 observed in the Volcker era. Furthermore, $\hat{\beta}$ (in absolute value) is far greater in the Volcker era than in the other subsample periods. ${ }^{22}$

The overall finding is that unconditional UIP, similarly to conditional UIP, dramatically fails in the Volcker era, whereas the violations of unconditional UIP are much weaker in the other subsample periods. By implication, the Volcker era significantly contributes to the development of the forward premium anomaly.

Finally, we employ Bai and Perron (2003)'s structural break tests for the abrupt changes in the mean of excess returns. We find that either 2 or 4 breaks occur over the entire sample period depending on the test and the aggregate considered. ${ }^{23}$ In all cases, the estimated break dates include 1980:2 and 1985:3. This result is broadly consistent with our sample division. More strikingly, as shown in Figure 8, these break dates coincide with both a period of the persistent appreciation of the US

\footnotetext{
${ }^{21}$ Here, we calculate aggregate excess returns and the corresponding interest rate differences between US and its trading partner by the GDP-weighted averages of individual excess returns and interest rate differences, following the convention in the literature of the forward premium anomaly. So an aggregate excess return is interpreted as a GDP-weighted portfolio. We also consider those variables constructed by the aggregation method in the Appendix. The results are very similar between the two methods, suggesting robustness of our results along this direction.

${ }^{22}$ This result is consistent with Moon and Velasco (2012), who found that significant deviations from UIP primarily occur in the 1980s when 1-, 3-, 6-, 12-month forward exchange rates are used.

${ }^{23}$ We relegate the details to Table S2 in the Online Supplement. The matlab files for running the tests are obtained from Pierre Perron's web page.
} 


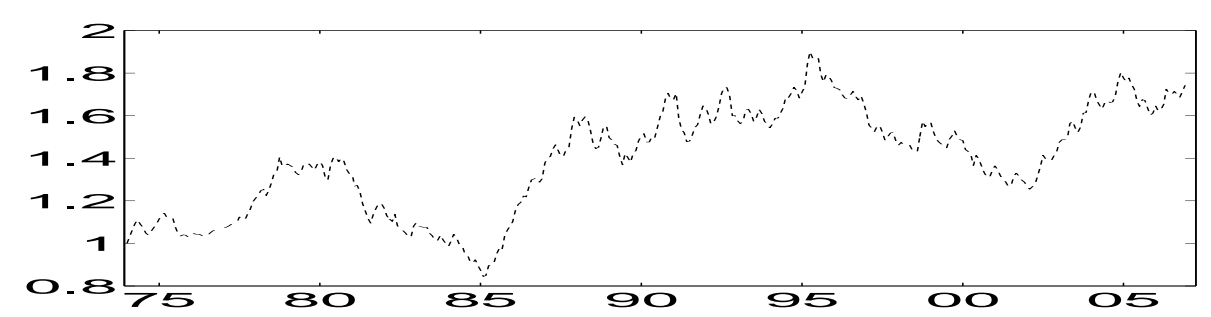

US long term interest rates and inflation rates

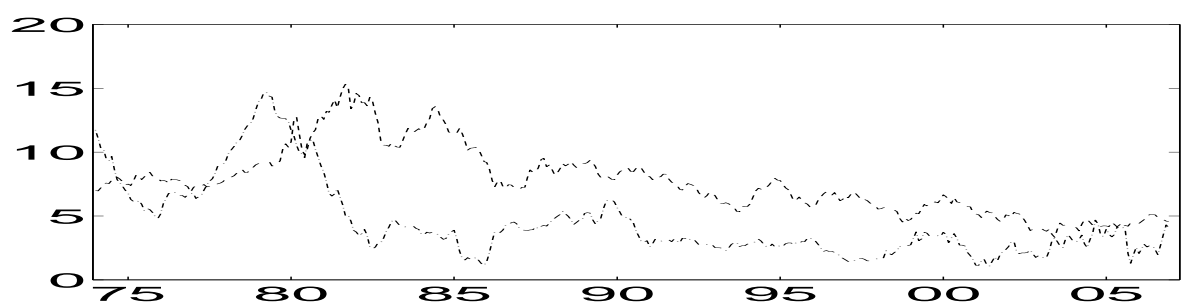

The US-AGG nominal exchange rate is normalized by the value in 1974:1. The dashed line in the lower panel represents US 10-year bond rates (percent per annum) and the dash-dot line represents 1-year ahead US inflation rate (annual percentage change of CPI).

Figure 8: Nominal exchange rates, long term interest rates, and inflation rates

dollar in the 1980s and a period of a historically high difference between the longterm interest rate and inflation. Bearing in mind that the persistent appreciation is a common feature underlying delayed overshooting and a violation of UIP, we turn to an explanation for our empirical findings presented so far in the next section.

\section{Incredible Volcker Disinflation}

We have documented the conditional behavior of exchange rates following US monetary policy shocks over four sample periods including three mutually exclusive subsample periods and the entire sample period, and have established that delayed overshooting is primarily a phenomenon of the Volcker era. We have also shown that both conditional and unconditional UIP are only significantly violated during the Volcker era. Furthermore, we have shown that the unconditional exchange rate movement in terms of serial dependence of exchange returns over long horizons is distinct in the Volcker era and closely reflects delayed overshooting behavior. Fi- 
nally, we have demonstrated that simply examining the entire sample period leads to an erroneous conclusion regarding the true behavior of exchange rates, as the effect of the Volcker era dominates the effects of the other sample periods. In this section, we examine why the Volcker era has such extraordinary and overwhelming impacts.

We regard the imperfect credibility of the Volcker Fed's disinflation policy in the early 1980s as a primary reason for the violations of both the overshooting hypothesis and UIP. We begin with historical episodes and evidence from this period, based on the analysis of Goodfriend and King (2005). At its onset, the Volcker Fed's disinflation plan was not considered to be credible by contemporary observers in the late 1970s and early 1980s. Over the two decades prior to the Volcker's chairmanship at the Fed, the annual pace of inflation rose by more than tenfold from below $1 \%$ to above $10 \%$, albeit with some fluctuations. The generation-long inflation and a series of adverse real shocks in the 1970s created the public perception that inflation was a permanent phenomenon. In addition, there was consensus that disinflation could be costly yet be accompanied by unemployment in the short run. ${ }^{24}$ The longstanding impression of inevitable inflation and costly disinflation is one of the reasons that made the Volcker Fed's goal appear not to be credible.

Moreover, the early course of the Volcker Fed led to a further loss of credibility concerning the disinflation plan. Volcker himself, near the beginning of his tenure as chairman, repeatedly promised monetary tightening in hearings. Further, the Volcker Fed clearly indicated that it at least intended to slow pace of inflation if it were unable to immediately achieve disinflation. Unfortunately, despite their antiinflation stance, the economy experienced rapid inflation, reaching $14.6 \%$ (record high postwar CPI inflation) in March 1980. The Fed's reaction to this inflation was aggressive, increasing to the federal funds rate to $17.6 \%$ in April 1980. However, by that point, the signs of a recession were already becoming clear. In response to this recession, the Fed made its first policy " $U$-turn" by cutting the federal funds rate by approximately 8 percentage points in the subsequent months. This substantial swing in policy at the first signs of recession made discerning the true intentions of

\footnotetext{
${ }^{24}$ See, e.g., Okun (1978)'s survey on the estimates of Phillips curves.
} 
the Volcker regime increasingly difficult for the public.

The US economy experienced another recession between late 1981 and 1982. On the other hand, the public observed that inflation had been curbed to a rate of $4 \%$ by late 1982 - the first observation of inflation in the $4 \%$ range since March 1973. We now know that this moment was truly remarkable because from that point onward, US inflation was consistently contained within a range of 1.5-4.5\% throughout the Volcker Fed's remaining tenure (and even beyond). However, for the public of the 1980s, these events had yet to occur. The 10-year Treasury bond rate reacted little to the massive decline in inflation experienced during the 1981-82 recession and remained above $10 \%$ until October 1985 . This delayed reaction to inflation on the part of nominal bond returns led to a historically high difference between the long-term interest rate and inflation, which was three times higher, on average, during the 1982-85 period relative to the entire postwar period (see Figure 8). Both the magnitude and the duration of this difference indicate that the public was continuously expecting a return to a high-inflation regime. The Volcker Fed's disinflation plan was not considered credible. The Fed was also aware of this perception: "[W]e've had a heck of a difference in the interest rate structure since '79, in those terms, which one can interpret as the American people giving up on the idea that we were ever going to return to price stability", Volcker remarked (FOMC transcript, August 1981; p.39).

This perception of the possibility of a monetary policy U-turn under the Volcker Fed may have triggered the persistent appreciation of the US dollar between 1980 and 1985. For instance, Gourinchas and Tornell (2004) develop an expectational error model in which the adjustment of exchange rates can be protracted when the public underestimates the effective horizon of a contractionary monetary shock. They further show that this underestimation can generate expectational errors that are sufficiently large to explain both the delayed overshooting and the forward premium puzzles. Interestingly, we have not yet observed significant evidence that monetary policy was not regarded as credible during the post-Volcker era, when UIP tends to hold and when exchange rates nearly immediately overshoot. To the extent that the imperfect credibility of monetary policy is a primary source of 
expectational errors, our story can explain both the delayed overshooting and UIP violations during the Volcker era and the immediate overshooting and UIP during the post-Volcker era.

Furthermore, the tremendous credibility problem facing the Volcker Fed may also explain why the effects of the Volcker era are so overwhelming that both the conditional and unconditional behaviors of exchange rates in the entire sample period appear to be quite similar to those in the Volcker era. Two of our results help elucidate this phenomenon: (i) the strong positive serial dependence of 3month excess returns over long horizons during the Volcker era (Figure 7) and (ii) the strong positive serial dependence of real exchange returns over long horizons during the Volcker era (Figure 5). These results show that both returns exhibit qualitatively the same pattern of serial dependence and that they may contain a common, nonstationary trend component. ${ }^{25}$ Interestingly, the behavior of US longterm bond rates during the 1980s provides a clue to the presence of the trend component in the returns. As discussed above, the long-term bond rates indicate that market participants continued to expect a policy U-turn between 1980 and 1985, despite the massive monetary contraction. In turn, this long-lived imperfect credibility may have generated substantial expectational errors and thus induced the trend of the US dollar appreciation during this period, which is the common feature underlying delayed overshooting and a violation of UIP. ${ }^{26}$

\footnotetext{
${ }^{25}$ Obviously, returns will exhibit negative serial dependence over long horizons if they contain a stationary predictable component. See, e.g., Fama and French (1988) and Moon and Velasco (2012, 2013). Moon and Velasco (2012) further present evidence that the ADF test does not reject the unit root hypothesis only for the Volcker era and the KPSS test rejects the stationary hypothesis only for the Volcker era by using weekly 3-, 6-, and 12-month excess returns.

${ }^{26}$ Numerous studies have investigated the trend path of US bilateral rates during the 1980s. For example, based on the assumption of heterogeneous expectations, Frankel and Froot (1990) consider the possibility of speculative bubbles. In their model, the market expectation is formed based on the weighted average of forecasts by fundamentalists and chartists, and this weight is updated based on a Bayesian rule regarding the past performance of these two agents. They show that the weight in the market expectation gradually shifts from the fundamentalists' forecasts to the chartists' forecasts during the 1980-85 period, as the forecasts of the fundamentalists continuously turned out to be wrong and a speculative bubble arose as a result. Even if the (exogenously given) chartists' forecasts are consistent with the US dollar appreciation path, their model takes the initial US dollar appreciation path as given for a bubble to emerge. See also Engel and Hamilton (1990) and Lewis (1989) who model a peso problem and rational learning, respectively, to explain the large swings in the US dollar during the 1980s.
} 


\section{Conclusions}

We have re-investigated the delayed overshooting puzzle and have obtained several new empirical facts. First, delayed overshooting is primarily a phenomenon of the 1980s when the Fed was under the chairmanship of Paul Volcker. Second, UIP fails to hold in the 1980s but tends to hold for the other periods. These results support Dornbusch's (1976) overshooting hypothesis. Third, US monetary policy shocks have substantial impacts on exchange rate fluctuations but appear to have small impacts when the subsample periods are pooled. This result suggests that the monetary policy regime itself is central to the explanation of exchange rate fluctuations attributable to monetary policy shocks. Fourth, the Volcker era shows strong delayed overshooting of exchange rates and a positive hump-shaped pattern of serial dependence of exchange returns. This result suggests that unconditional exchange rate movements inherit conditional movements due to monetary policy shocks. Connecting all these results to derive a single consistent explanation, we conclude that exchange rate movements and UIP are as cohesively related in data as they are in theory.

We highlight credibility as a possible reason that the Volcker era is so different and influential relative to other periods. To the extent that credibility matters in economic dynamics, we hope this lesson can advance the study of policy in general. Possible research areas include the international transmission mechanisms of economic policy. For example, while acknowledging the need for rigorous analysis including all details of transmission mechanisms, such as trade balance movements, we argue that future research should emphasize the importance of monetary policy regimes when assessing the impact of a home country's monetary policy on foreign welfare. If a central bank's credibility affects the timing and size of market responses to shocks, its credibility will also affect the relative dominance of various transmission channels, such as expenditure switching, income absorption, and world demand effects. Whether to beggar thy neighbor or to beggar thyself would rely on how credible thou art. 


\section{References}

Andrews, Donald. 1993. "Tests for Parameter Instability and Structural Change With Unknown Change Point." Econometrica 61 (4):821-856.

Bai, Jushan and Pierre Perron. 2003. "Computation and Analysis of Multiple Structural Change Models." Journal of Applied Econometrics 18 (1):1-22.

Bernanke, Ben S., Jean Boivin, and Piotr Eliasz. 2005. "Measuring the Effects of Monetary Policy: A Factor-Augmented Vector Autoregressive (FAVAR) Approach." Quarterly Journal of Economics 120 (1):387-422.

Bernanke, Ben S. and Ilian Mihov. 1998. "Measuring Monetary Policy." Quarterly Journal of Economics 113:869-902.

Binder, Michael, Qianying Chen, and Xuan Zhang. 2010. "On the Effects of Monetary Policy Shocks on Exchange Rates." CESifo Working Paper No. 3162 .

Bjornland, Hilde C. 2009. "Monetary Policy and Exchange Rate Overshooting: Dornbusch Was Right After All." Journal of International Economics 79:64-77.

Clarida, Richard and Jordi Gali. 1994. "Sources of Real Exchange Rate Fluctuations: How Important Are Nominal Shocks?" Carnegie-Rochester Conference Series on Public Policy 41:1-56.

Clarida, Richard, Jordi Gali, and Mark Gertler. 2000. "Monetary Policy Rules and Macroeconomic Stability: Evidence and Some Theory." Quarterly Journal of Economics 115 (1):147-180.

Cushman, David O. and Tao Zha. 1997. "Identifying Monetary Policy in a Small Open Economy under Flexible Exchange Rates." Journal of Monetary Economics 110:433-448.

Dornbusch, Rudiger. 1976. "Expectations and Exchange Rate Dynamics." Journal of Polictical Economy 84:1161-1176. 
Eichenbaum, Martin and Charles L. Evans. 1995. "Some Empirical Evidence on the Effects of Shocks to Monetary Policy on Exchange Rates." Quarterly Journal of Economics 110:975-1009.

Engel, Charles. 1996. "The Forward Discount Anomaly and the Risk Premium: A Survey of Recent Evidence." Journal of Empirical Finance 3:123-192.

Engel, Charles and James D. Hamilton. 1990. "Long Swings in the Dollar: Are They in the Data and Do Markets Know It." American Economic Review 80:689-713.

Fama, Eugene F. and Kenneth R. French. 1988. "Permanent and Temporary Components of Stock Prices." Journal of Political Economy 96 (2):246-273.

Faust, Jon and John H. Rogers. 2003. "Monetary Policy's Role in Exchange Rate Behavior." Journal of Monetary Economics 50:1403-1424.

Forni, Mario and Luca Gambetti. 2010. "The Dynamic Effects of Monetary Policy: A Structural Factor Model Approach." Journal of Monetary Economics 57 (2):203-216.

Frankel, Jeffrey A. and Kenneth A. Froot. 1990. "Chartists, Fundamentalists, and Demand for Dollars." In Private Behavior and Interdependent Government Policy. Oxford: Clarendon Press, anthony s. courakis and mark p. taylor, ed ed.

Fry, Renee and Adrian Pagan. 2011. "Sign Restrictions in Structural Vector Autoregressions: A Critical Review." Journal of Economic Literature 49 (4):938-960.

Gali, Jordi and Luca Gambetti. 2009. "On the Sources of the Great Moderation." American Economic Journal: Macroeconomics 1 (1):26-57.

Gali, Jordi, J.David Lopez-Salido, and Javier Valles. 2003. "Technology Shocks and Monetary Policy: Assessing the Fed's Performance." Journal of Monetary Economics 50 (4):723-743.

Goodfriend, Marvin and Robert G. King. 2005. "The Incredible Volcker Disinflation." Journal of Monetary Economics 52:981-1015. 
Gourinchas, Pierre-Olivier and Aaron Tornell. 2004. "Exchange Rate Puzzles and Distorted Beliefs." Journal of International Economics 64:303-333.

Grilli, Vittorio and Nouriel Roubini. 1996. "Liquidity Models in Open Economies: Theory and Empirical Evidence." European Economic Review 40:847-859.

Judd, John and Glenn Rudebusch. 1998. "Taylor's Rule and the Fed: 1970-1997." Economic Review-Federal Reserve Bank of San Francisco :3-16.

Kim, Soyoung. 2005. "Monetary Policy, Foreign Exchange Policy, and Delayed Overshooting." Journal of Money, Credit and Banking 37:775-782.

Kim, Soyoung and Nouriel Roubini. 2000. "Exchange Rate Anomalies in the Industrial Countries: A Solution with a Structural VAR Approach." Journal of Monetary Economics 45:561-586.

Leeper, Eric M. and David B. Gordon. 1992. "In Search of the Liquidity Effect." Journal of Monetary Economics 29 (3):341-369.

Lewis, Karen K. 1989. "Changing Beliefs and Systematic Rational Forecast Errors with Evidence from Foreign Exchange." American Economic Review 79 (4):621636.

1995. "Puzzles in International Financial Markets." In Handbook of International Eonomics, vol. 3. Amsterdam: Elsevier, gene grossman and kenneth rogoff eds. ed., 1913-1971.

Moon, Seongman and Carlos Velasco. 2012. "The Strong Predictability of US Dollar Excess Returns in the 1980s." mimeo Universidad Carlos III de Madrid.

— 2013. "Tests for m-dependence Based on Sample Splitting Methods." Journal of Econometrics 173:143-159.

Okun, Arthur M. 1978. "Efficient Disinflationary Policies." American Economic Review (Papers and Proceedings) 68 (2):348-352.

Reichenstein, William. 1987. "The Impact of Money on Short Term Interest Rates." Economic Inquiry 25 (1):67-82. 
Scholl, Almuth and Harald Uhlig. 2008. "New Evidence on the Puzzles: Results from Agnostic Identification on Monetary Policy and Exchange Rates." Journal of International Economics 76:1-13.

Sims, Christopher A. 1992. "Interpreting the Macroeconomic Time Series Facts: The Effects of Monetary Policy." European Economic Review 36:975-1000.

Stock, James H. and Mark W. Watson. 2002. "Has the Business Cycle Changed and Why?" NBER Macroeconomics Annual :159-218.

Taylor, John B. 1999. "A Historical Analysis of Monetary Policy Rules.” In Monetary Policy Rules. University of Chicago Press, john b. taylor, eds. ed., 319-348.

Uhlig, Harald. 2005. "What are the Effects of Monetary Policy on Output? Results from an Agnostic Identification Procedure." Journal of Monetary Economics $52(2): 381-419$. 


\section{Appendix}

\section{Data Sources and Aggregation}

Table A1: Data sources

\begin{tabular}{c|c|c}
\hline Variable & Description & Source \\
\hline \hline$y$ & Index of US industrial production & IFS line 66 \\
\hline$y^{*}$ & Index of Foreign industrial production & IFS line 66 \\
\hline$p$ & US consumer price index & IFS line 64 \\
\hline$p^{*}$ & Foreign consumer price index & IFS line 64 \\
\hline$i$ & US treasury bill rate & IFS line 60c \\
\hline$f$ & Federal funds rate & IFS line 60b \\
\hline$i^{*}$ & Foreign short-term interest rate & IFS line 60b or 60c \\
\hline \multirow{2}{*}{$n b r x$} & US nonborrowed reserves & Fed. Reserve Bank \\
& plus extended credit/total reserves & St. Louis \\
\hline \multirow{2}{*}{$s$} & Nominal exchange rate in dollar & Fed. Reserve Bank \\
& per foreign currency & St. Louis \\
\hline$s-p+p^{*}$ & Real exchange rate per foreign goods & \\
\hline
\end{tabular}

We use treasury bill rates if short-term interest rates are not available for $i^{*}$.

For constructing aggregates, we follow the method by Scholl and Uhlig (2008). First, we calculate weight for each country by dividing the country's GDP by the total GDP at purchasing power parity values. Second, we take growth rates for each individual country. Third, the aggregate growth rates are calculated by the weighted sum of the individual growth rates. Finally, the levels are calculated by cumulating aggregate growth rates from the initial base year. Refer to Data Appendix for the replication of our results.

\section{Results for Individual Country Pairs}

The following figures show two key results for non-EMU countries and GE which are used in the construction of the aggregates based on AGG. We relegate the results for EMU countries to the Online Supplement. 


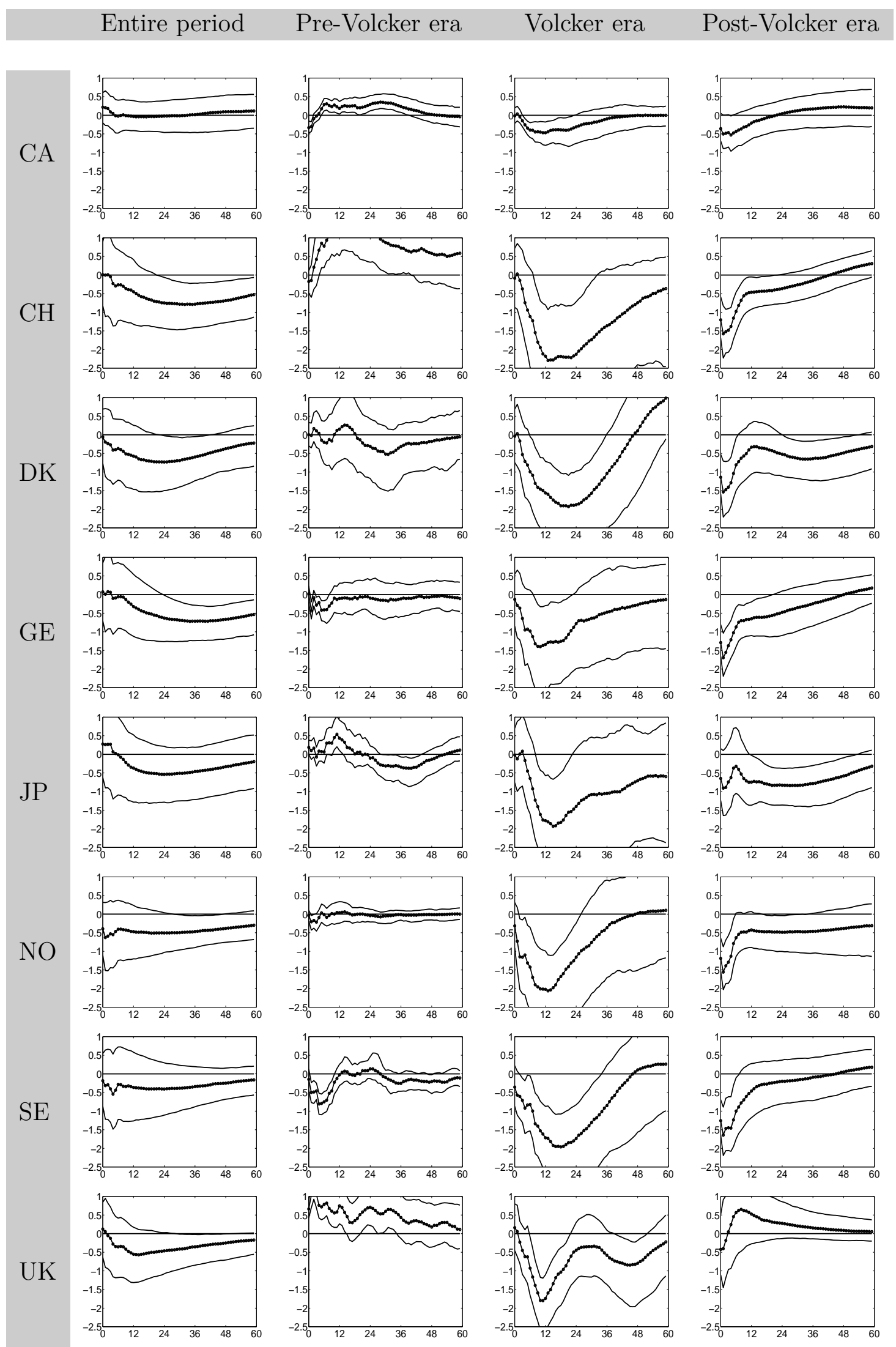

Figure B1: Impulse responses of real exchange rates (individual country pairs) 


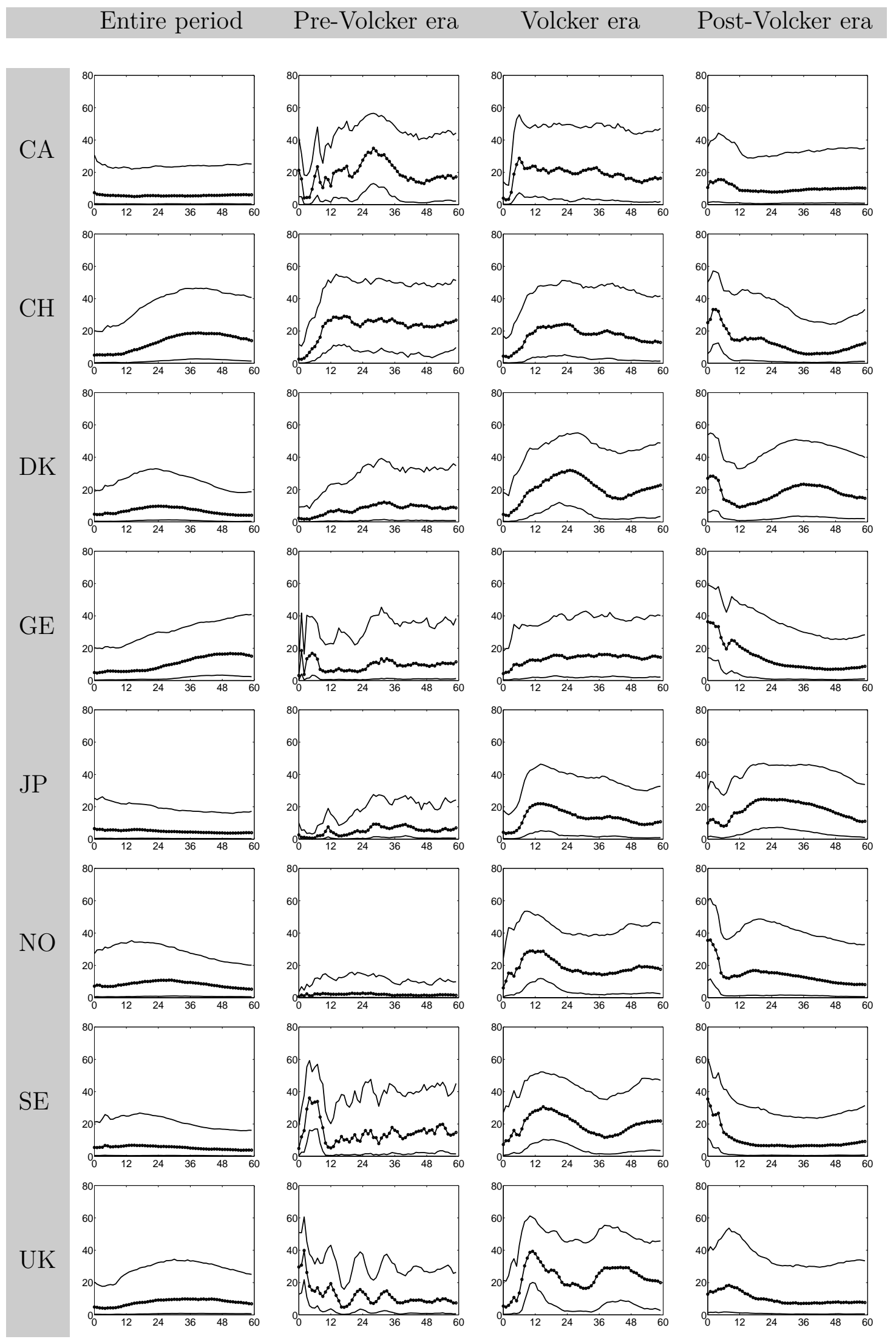

Figure B2: Forecast error variance decomposition for real exchange rate fluctuations (individual country pairs) 